\title{
Annual yield and botanical composition of four dryland grass species with or without nitrogen over six years
}

\author{
Marcus V. TALAMINI JUNIOR*, Shirin SHARIFIAMINA, Elsa A. DAVID, \\ Annamaria MILLS and Derrick J. MOOT \\ Dryland Pastures Research Group, Lincoln University, P.O. Box 85084, Lincoln 7647, New Zealand \\ *Corresponding author: marcus.talaminijunior@lincolnuni.ac.nz
}

\begin{abstract}
Nitrogen $(\mathrm{N})$ and water availability affect pasture production and persistence. Yield and botanical composition of four monocultures of brome (BR), cocksfoot $(\mathrm{CF})$, perennial ryegrass $(\mathrm{RG})$ and tall fescue $(\mathrm{TF})$ were evaluated with $(+\mathrm{N})$ or without $(-\mathrm{N}) \mathrm{N}$ at Ashley Dene farm, Canterbury, over six growth seasons from establishment in 2014/15 (Year 1) to 2019/20 (Year 6). Total annual yields ranged from 2.04 (RG-N; Year 1) to $12.7 \mathrm{t} \mathrm{DM} / \mathrm{ha} / \mathrm{yr}(\mathrm{CF}+\mathrm{N}$; Year 3$)$. Yields differed among species in Years 1, 3, 4 and 6 when TF pastures had the lowest production. There was no difference in $\mathrm{DM}$ production from $\mathrm{BR}, \mathrm{CF}$ and $\mathrm{RG}$ pastures. Additionally, $+\mathrm{N}$ pastures produced $\sim 55 \%$ more yield than $-\mathrm{N}$ pastures in Years 3 and 5 when spring/summer rainfall was adequate to maintain growth. Sown grasses accounted for $>89 \%$ of total DM yield in Years 1 and 2 but the proportion of total annual DM production from sown species declined from Year 3. By Year 6, sown species accounted for $48 \pm 3.3$ (TF) to $64 \pm 3.3 \%$ (BR, $\mathrm{CF}$ and $\mathrm{RG}$ ) of total annual DM production. Generally, $\mathrm{TF}$ failed to perform in this dryland environment. In contrast, the production and persistence of the other three species were not different when subjected to water deficits alone.
\end{abstract}

Keywords: Bromus valdivianus, Dactylis glomerata, Festuca arundinacea, Lolium perenne, persistence

\section{Introduction}

In summer-dry environments, abiotic and biotic factors affect pasture production and persistence. Previously, Milne (2011) reported regional variation in perennial ryegrass persistence was associated with moisture availability (rainfall + irrigation), summer temperatures and pest/disease pressure. He concluded that species selection should be based on tolerance to the environment in which it is sown. As seasonal water deficits develop, leaf expansion is initially affected (Brown 1995), which reduces total light interception from reduced ground cover. Insufficient water supply to meet plant demand also reduces nutrient uptake from soil solution (Mills et al. 2009) and increased heat load on the plants as stomata close which decreases cooling from transpiration (Jamieson et al. 1995). Once the soil surface is dry, evaporative cooling also stops so daytime soil surface temperatures can increase to $>40$ ${ }^{\circ} \mathrm{C}$ (unpublished data). These high temperatures are detrimental to plant survival, particularly for shallow rooted species like white clover (Knowles et al. 2003; Power et al. 2006) and contribute to the loss of sown species, depending on the extent, duration, severity and timing of the stress period. Stevens et al. (2021) recently reported pasture production, persistence, and water use efficiency were also affected by nutrient supply, particularly nitrogen (N). On-farm management of $\mathrm{N}$ can therefore affect resource use efficiency simply based on species selection.

Pasture renewal has been estimated at $\$ 1020 /$ ha (dairy) to $\$ 1120 /$ ha (sheep, Barenbrug New Zealand 2021). Financially, long-term pasture productivity and persistence has several benefits. First, introduction of newer genetic material with improved productivity traits selected for higher DM yields and palatability, plus improved pest and disease tolerance, than resident pasture species. However, these production gains may not be maintained long-term (Chapman et al. 2021). Secondly, persistent pastures are renewed less frequently, which dilutes initial seed, agrichemical and cultivation costs across the lifetime of the pasture. In New Zealand $6-8 \%$ of dairy pastures are renewed annually (Sanderson \& Webster (2009) and Pasture Renewal Charitable Trust (2013) cited in Kerr et al. 2015). Lower productivity, grass-based hill country sheep and beef pastures can be aged $>30$ years (Mills et al. 2021) and well managed dryland lucerne stands can remain productive for $>10$ years (Mills et al. 2014). Predicted climate change scenarios for the east coast of New Zealand also suggest temperatures will increase and summer-dry conditions will intensify (Salinger 2003). This will affect both crop and pasture species selection given global mitigation strategies are currently insufficient to prevent these changes (IPCC 2021). Climate change scenarios for New Zealand (Ministry for the Environment 2018) predict a reduction in the number of cold nights and an increase in days with temperatures above the optimum for temperate species, which are expected to reduce potential growth even when soil moisture is non limiting. The impact is predicted to be greatest in summer-dry environments with an increase in the duration and intensity of water 
deficits being detrimental to the ability of some current species to survive and recover. Additionally, earlier onset of water deficits (spring drought) reduces the period of reliable spring growth that dryland pastoral farmers rely on to grow production stock before feed supply declines over summer. This may increase reliance on specialist pastures, such as lucerne (Moot et al. 2019), or forage crops to maintain production levels and animal condition. However, perennial grass-based pastures are likely to remain important components of feed supply on many dryland farms because they offer flexible grazing management, provide a low-cost feed source and can add to farm resilience. The aim of this research was to compare the production and persistence of four commonly sown perennial grasses in a summerdry environment. The dry matter (DM) yield and quality of each species in response to applied $\mathrm{N}$ was also determined.

\section{Materials \& Methods}

\section{Site characteristics}

Prior to establishment, the site (Paddock C8, Ashley Dene Research Farm, Canterbury, $43^{\circ} 39^{\prime} \mathrm{S}, 172^{\circ} 20^{\prime} \mathrm{E}$, $30 \mathrm{~m}$ a.s.1.) had not been cultivated for $>60$ years and resident species included browntop (Agrostis capillaris), cocksfoot, twitch (Elymus repens), white clover (Trifolium repens), fathen (Chenopodium album) and wireweed (Polygonum aviculare, Sharifiamina 2018). The soil is an imperfectly drained Lowcliffe stony soil (Mottled Argillic Pallic) with $75-89 \mathrm{~mm} / \mathrm{m}$ of plant available water in the top $1.0 \mathrm{~m}$ of the soil profile (McLenaghen \& Webb 2012).

\section{Environmental conditions}

Long-term mean (LTM, 1970-2010; Burnham Sewage Plant, National Institute of Water and Atmospheric Research (NIWA) Cliflo Agent No. 4880) annual rainfall is $643 \mathrm{~mm}$ and averages $\sim 48 \mathrm{~mm} /$ month from September-April increasing to $\sim 65 \mathrm{~mm} / \mathrm{month}$ from May-August (Figure 1a). During the experimental period rainfall averaged $572 \mathrm{~mm} /$ growth season (JulyJune) and ranged from a minimum of $422 \mathrm{~mm}$ in the establishment year $(2014 / 15)$ to a maximum of $875 \mathrm{~mm}$ in 2017/18 (Year 4). Monthly rainfall ranged from a minimum of $1 \mathrm{~mm}$ (January 2020) to a maximum of $153 \mathrm{~mm}$ (July 2017). Rainfall was below the LTM in 42 of 72 months, or $58 \%$ of the time.

Mean monthly air temperatures followed the expected seasonal pattern typical of temperate climates with LTM (1975-2010; Lincoln, Broadfield, NIWA Cliflo Agent No. 17603) increasing from a minimum of $6.1^{\circ} \mathrm{C}$ in July to a maximum of $16.6{ }^{\circ} \mathrm{C}$ in January (Figure 1b). Over the observation period, monthly temperatures ranged from $5.5^{\circ} \mathrm{C}$ (July 2017; Year 4) to $18.9^{\circ} \mathrm{C}$ (February 2016; Year 3).

\section{Soil moisture deficit}

A potential soil moisture deficit (PSMD; mm) was calculated from rainfall and potential evapotranspiration (PET) and was reset to zero on 1 July (Figure 2). Prior to initiation of PET calculations using environmental data collected on-site (1/6/2017), PET data from Broadfield EWS station were substituted into the equation. The maximum PSMD ranged from $343 \mathrm{~mm}$ (2017/18; Year 4) to $686 \mathrm{~mm}(2014 / 15$; Year 1). The soil moisture deficit (SMD) was then calculated from a soil water budget based on an estimated plant available water content (PAWC) in the top $1.0 \mathrm{~m}$ of the soil profile of $89 \mathrm{~mm}$ expected in a Lowcliffe stony soil (Manaaki Whenua - Landcare Research 2019). When half PAWC was depleted, soil water use was constrained proportionally (NIWA 2019) to reflect the plant water extraction being limited as the soil dries. The SMD reached the maximum in all years and from late October rainfall was insufficient to meet evaporative demand. This meant that over the six growth seasons estimated daily water use was less than PET for 104 (2017/18; Year 4) to 234 days (2014/15; Year 1). Late autumn/winter rainfall recharged soil moisture back to field capacity by July each year.

\section{Experimental design}

A strip plot experiment with four replicates was established, following conventional cultivation practices, on 15 October 2014. Four pasture grasses ('Bareno' pasture brome (BR), 'SFR36-009' cocksfoot (CF), 'Stellar' AR1 perennial ryegrass (RG) and the Oceanic type 'Finesse Q' tall fescue (TF)) were established as monocultures. Sowing rates, germination and cultivar details are reported in Sharifiamina (2018). Soil test results (Table 2) showed nutrients were adequate so no maintenance fertiliser applications were required. From Year $2(2015 / 16)$ strips of $\mathrm{N}$ fertiliser created subplots $(6.3 \mathrm{~m} \times 10.0 \mathrm{~m})$ to quantify the effect of $\mathrm{N}$ fertility on pasture growth. The $\mathrm{N}$ application rate ranged from 205 (Year 6) to $500 \mathrm{~kg} \mathrm{~N} / \mathrm{ha} / \mathrm{yr}$ (Year 2) depending on the number of grazing periods. Grazing was based on having sufficient herbage to harvest as would be expected on a commercial farm (between 2 and $3 \mathrm{t} \mathrm{DM/ha).} \mathrm{As} \mathrm{such,}$ regrowth interval and the number of grazing events per year differed due to low pasture growth in periods of water deficits in summer/autumn and low temperature in winter (Table 1). Nitrogen was generally applied in the first week of regrowth. However, when water was limiting growth, $\mathrm{N}$ applications were deferred until rainfall was forecast. The longest deferral was $\sim 4$ weeks in Year 4 when $\mathrm{N}$ application for the grazing period beginning in November was applied late December with herbage harvested in late January. 

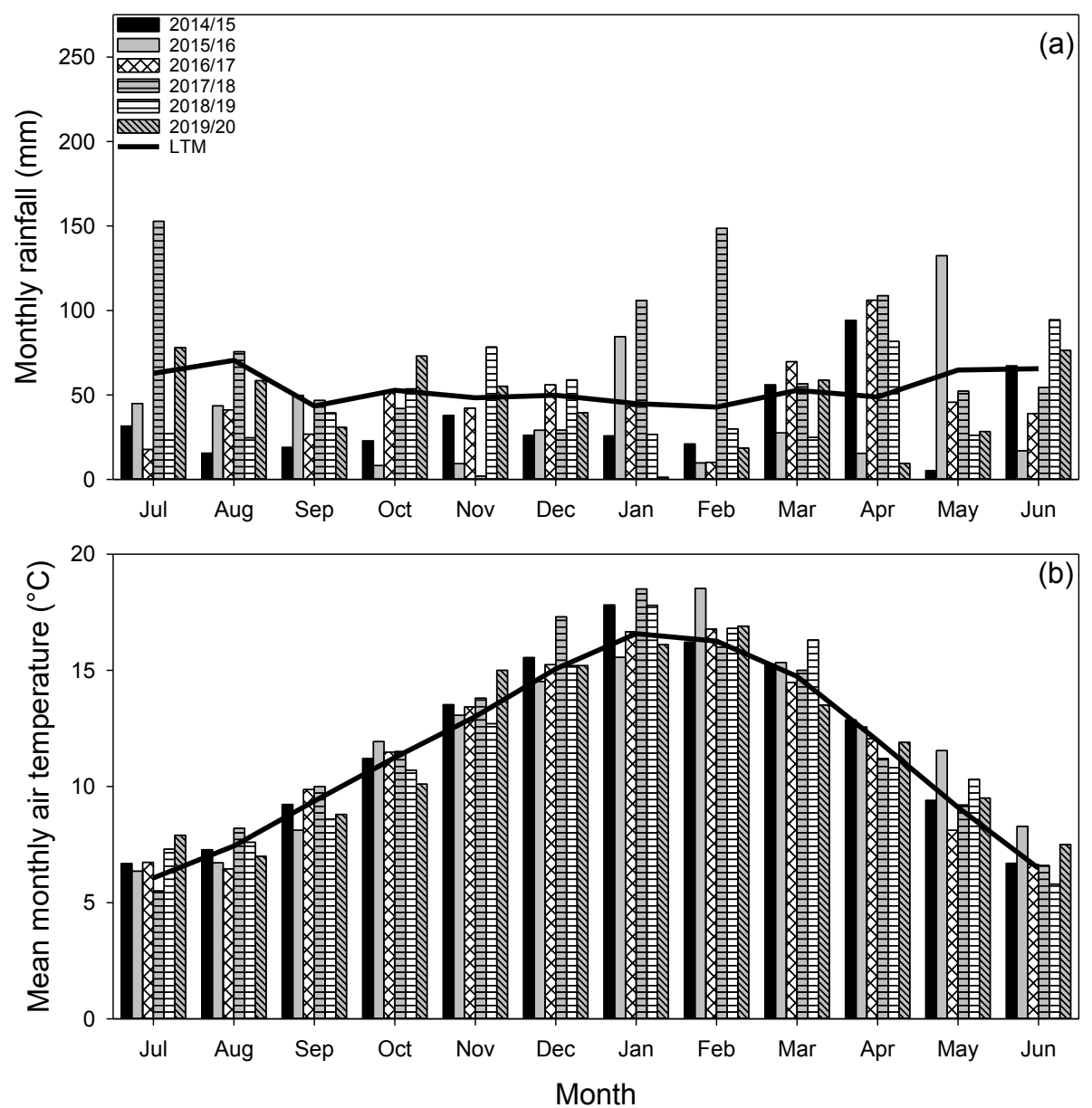

Figure 1 Monthly (a) rainfall $(\mathrm{mm})$ and $(\mathrm{b})$ mean air temperature $\left({ }^{\circ} \mathrm{C}\right)$ recorded at Ashley Dene, Canterbury, New Zealand from 2014/15 (Year 1) to 2019/20 (Year 6). Long-term means (LTM) data are from the closest NIWA stations and are for the period 1970-2010 (recorded at the Burnham Sewage Plant) for rainfall and 1975-2010 (recorded at Broadfield EWS).

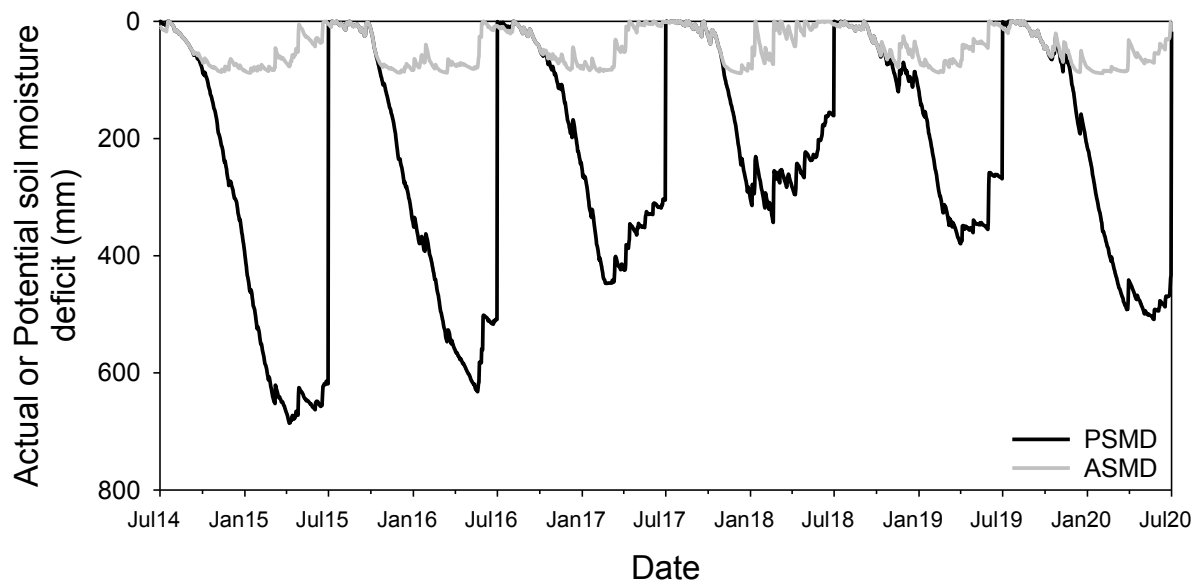

Figure 2 Actual (ASMD; $\mathrm{mm}$ ) and potential (PSMD; $\mathrm{mm}$ ) soil moisture deficit over six growth seasons at Ashley Dene, Canterbury, New Zealand. The PSMD is re-zeroed on 1 July. The soil water budget is based on $89 \mathrm{~mm}$ of plant available water in the top $1.0 \mathrm{~m}$ of the soil profile for a Lowcliffe stony soil and potential water use is proportionally restricted when more than half PAWC has been depleted. 


\section{Management}

In Years 1-4 pastures were grazed in common by sheep at the end of each regrowth interval because surface stones meant mowing was not possible without damaging equipment. In Year 5, pastures were grazed following harvest in Regrowth Intervals 1 and 2 . Subsequently, cut and carry management was able to be initiated with a larger mower from November 2018, and continued until the end of the experiment.

On 4 May 2015, 3.0 L/ha Trimec (600 g/L mecoprop, $150 \mathrm{~g} / \mathrm{L} \mathrm{MCPA}$ and $18.7 \mathrm{~g} / \mathrm{L}$ dicamba) was applied to control the broadleaf weeds in the grass monocultures.

\section{Yield and botanical composition}

Dry matter yield was determined from a representative $0.2 \mathrm{~m}^{2}$ quadrat cut to a residual height of $3.0 \mathrm{~cm}$ in each plot at the end of each regrowth interval, before grazing. There were 3-8 regrowth intervals annually. Subsamples were taken (Cayley \& Bird 1996) and separated into sown grass, weeds, and dead material. In Years 5 and 6 the sown grass was further separated into vegetative and reproductive sub-categories. Samples were then dried in a forced air oven at $60{ }^{\circ} \mathrm{C}$ until constant weight.

\section{Metabolisable energy}

In Years 5 and 6, metabolisable energy (ME, MJ/kg DM) was determined for vegetative and reproductive sown grass components. Dried samples were ground (Ultracentrifugal mill ZM200, Retsch, Germany) to achieve a particle size $<1 \mathrm{~mm}$. Samples were analysed in a Foss NIR Systems 5000 Rapid Content Analyser (Welltech Scientific Inc, Chantilly, VA, USA).

\section{Statistical analysis}

Data were analysed by ANOVA in Genstat v. 20 (VSN International Ltd.). In the establishment year (Year 1), prior to the initiation of $\mathrm{N}$ treatment, the experiment was analysed as a Latin Square design. In Years 2-6 data were analysed as a strip plot design with grass species and $\mathrm{N}$ level as treatments. When significant, means were separated by Fishers' protected LSD at the $\mathrm{a}=0.05$ level. Repeated measures analysis evaluated the ME of vegetative sown grasses at six dates in Years 5 and 6. Treatment means are reported with the standard error of the mean (SEM) associated with the effect described. When no treatment effect was observed the grand mean is reported with the pooled SEM. Grouped linear regression was used to explain the relationship between sown grass yield and total annual DM production. Linear regression was also used to evaluate the change in $\mathrm{ME}$ of sown grasses as the proportion of reproductive material present increased.

Table 1 Quantity of nitrogen $(\mathrm{N})$ fertiliser applied, as urea $(46 \% \mathrm{~N})$, to $+\mathrm{N}$ pasture treatments at Ashley Dene, Canterbury, New Zealand over six growth seasons. Where $\mathrm{N}$ application rates differed among grazing periods $(\mathrm{P})$ the quantity applied in specific periods is reported.

\begin{tabular}{lccc}
\hline Year & Number of grazing events & N applied (kg/ha) per period & Total N applied (kg N/ha/yr) \\
\hline $2014 / 15$ & 3 & 0 & 0 \\
$2015 / 16$ & 5 & 100 & 500 \\
$2016 / 17$ & 7 & $0(\mathrm{P} 1) ; 90(\mathrm{P} 2-5) ; 45(\mathrm{P} 6-7)$ & 450 \\
$2017 / 18$ & 8 & $0(\mathrm{P} 1) ; 90(\mathrm{P} 2-5) ; 45(\mathrm{P} 6-8)$ & 495 \\
$2018 / 19$ & 7 & $0(\mathrm{P} 1) ; 82(\mathrm{P} 2-5) ; 0(\mathrm{P} 6) ; 41(\mathrm{P} 7)$ & 369 \\
$2019 / 20$ & 4 & $0(\mathrm{P} 1) ; 82(\mathrm{P} 2-3) ; 41(\mathrm{P} 4)$ & 205 \\
\hline
\end{tabular}

Table 2 Soil test results at Ashley Dene, Canterbury, New Zealand. Note: no soil tests were taken from 2016-2018.

\begin{tabular}{|c|c|c|c|c|c|c|c|c|c|c|}
\hline \multirow{2}{*}{ Year } & \multirow{2}{*}{ Trt } & \multirow{2}{*}{$\begin{array}{c}\text { Sample } \\
\text { depth }(\mathrm{cm})\end{array}$} & \multirow{2}{*}{$\begin{array}{c}\mathrm{pH} \\
\left(\mathrm{H}_{2} \mathrm{O}\right)\end{array}$} & \multirow{2}{*}{$\begin{array}{l}\text { Olsen P } \\
(\mu \mathrm{g} / \mathrm{ml})\end{array}$} & \multirow{2}{*}{$\begin{array}{c}\text { Sulphate-S } \\
(\mu \mathrm{g} / \mathrm{g})\end{array}$} & $\mathrm{Ca}^{2+}$ & $\mathbf{K}^{+}$ & $\mathrm{Mg}^{2+}$ & $\mathrm{Na}^{2+}$ & \multirow{2}{*}{$\begin{array}{l}\text { Available } \\
N \text { (kg/ha) }\end{array}$} \\
\hline & & & & & & \multicolumn{4}{|c|}{$(\mathrm{meq} / 100 \mathrm{~g})$} & \\
\hline 2014 & & 15 & 5.4 & 19 & $\mathrm{nd}^{1}$ & 6.4 & 0.23 & 0.84 & 0.14 & $n d^{1}$ \\
\hline 2015 & & 15 & 5.5 & 12 & $n d^{1}$ & 6.3 & 0.17 & 0.75 & 0.15 & 88 \\
\hline 2019 & $+\mathrm{N}$ & 20 & 5.2 & 17 & 1 & 4.7 & 0.27 & 0.57 & 0.08 & $176^{2}$ \\
\hline 2019 & $-N$ & 20 & 5.7 & 9 & 2 & 5.7 & 0.24 & 0.80 & 0.14 & $188^{2}$ \\
\hline 2020 & & 20 & 5.8 & 36 & $n d^{1}$ & 12.9 & 0.23 & 1.92 & 0.30 & $218^{2}$ \\
\hline
\end{tabular}




\section{Results}

In the establishment year (2014/15), when no N fertiliser was applied, total DM yields were low but differed among species (Table 3). Specifically, the 2.74 t DM/ha/yr produced by the BR pasture was $35 \%$ more $(\mathrm{P} \leq 0.05)$ than the $2.04 \mathrm{t} \mathrm{DM} /$ ha from the TF pastures. The $2.44 \pm 0.13 \mathrm{t} \mathrm{DM} / \mathrm{ha}$ from the PR and CF pastures was not different to the other yields. In 2015/16, N fertiliser applications were initiated, and a $\mathrm{Spp} \times \mathrm{N}$ interaction was observed. The $\mathrm{CF}+\mathrm{N}$ pasture had the highest yield (5.92 t DM/ha/yr) which was $53 \%$ more $(\mathrm{P} \leq 0.001)$ than the $3.87 \pm 0.19 \mathrm{t} \mathrm{DM} / \mathrm{ha}$ from the $\mathrm{CF}-\mathrm{N}$, $\mathrm{RG}+\mathrm{N}$ and RG-N pastures. The lowest annual yield in 2015/16 was $2.75 \mathrm{t} \mathrm{DM}$ /ha from the BR-N pasture. The interaction predominantly resulted from a lack of response to applied $\mathrm{N}$ fertiliser by the $\mathrm{RG}$ and $\mathrm{TF}$ pastures.

For 2016/17, main effects dominated annual yield. The $10.8 \pm 0.56 \mathrm{t} \mathrm{DM} /$ ha produced by $+\mathrm{N}$ pastures was $56 \%$ greater $(\mathrm{P} \leq 0.05)$ than the $6.89 \pm 0.56 \mathrm{t} \mathrm{DM} / \mathrm{ha}$ produced by $-\mathrm{N}$ pastures. Additionally, TF had a $25 \%$ lower $(\mathrm{P} \leq 0.05)$ total annual yield $(7.08 \mathrm{t} \mathrm{DM} / \mathrm{ha})$ than the $9.41 \pm 0.55 \mathrm{t} \mathrm{DM} / \mathrm{ha}$ from $\mathrm{BR}, \mathrm{CF}$ and $\mathrm{RG}$ pastures. In $2017 / 18 \mathrm{TF}$ yield $(6.67 \mathrm{t} \mathrm{DM} / \mathrm{ha})$ was $17 \%$ lower $(\mathrm{P} \leq 0.01)$ than the $8.06 \pm 0.28 \mathrm{t} \mathrm{DM} / \mathrm{ha}$ produced by the BR, CF and RG pastures. In 2018/19 the $\mathrm{N}$ effect

Table 3 Total annual DM production ( $\mathrm{kg} \mathrm{DM} / \mathrm{ha} / \mathrm{yr}$ ) of brome (BR), cocksfoot (CF), perennial ryegrass (RG) and tall fescue (TF) monocultures fertilised with $(+\mathrm{N})$ or without $(-\mathrm{N})$ nitrogen at Ashley Dene, Canterbury, New Zealand over six growth seasons. In Year 2 (2015/16) the main effect significance levels are reported in brackets because the interaction was significant.

\begin{tabular}{|c|c|c|c|c|c|c|c|}
\hline \multirow[b]{2}{*}{ Species } & & \multicolumn{6}{|c|}{ Growth season } \\
\hline & & $2014 / 15$ & $2015 / 16$ & $2016 / 17$ & $2017 / 18$ & $2018 / 19$ & $2019 / 20$ \\
\hline BR & & $2.74 \mathrm{a}$ & 3.07 & $9.10 \mathrm{a}$ & $8.15 \mathrm{a}$ & 7.06 & 7.50 \\
\hline CF & & $2.48 a b$ & 4.97 & $10.1 \mathrm{a}$ & $8.29 a$ & 7.97 & 8.44 \\
\hline$R G$ & & $2.41 a b$ & 3.80 & $9.01 \mathrm{a}$ & $7.73 \mathrm{a}$ & 7.80 & 7.39 \\
\hline TF & & $2.04 \mathrm{~b}$ & 3.17 & $7.08 \mathrm{~b}$ & $6.67 \mathrm{~b}$ & 7.93 & 6.25 \\
\hline & Grand Mean & 2.42 & 3.75 & 8.83 & 7.71 & 7.69 & 7.39 \\
\hline & SEM & 0.13 & 0.14 & 0.55 & 0.28 & 0.47 & 0.47 \\
\hline & Significance $^{1}$ & * & $\left({ }^{\star \star}\right)$ & * & $\star \star$ & ns & ns \\
\hline
\end{tabular}

\section{Nitrogen level}

\begin{tabular}{|c|c|c|c|c|c|c|c|}
\hline$+\mathrm{N}$ & & -2 & 4.00 & $10.80 \mathrm{a}$ & 7.39 & $9.34 \mathrm{a}$ & 7.72 \\
\hline \multirow[t]{3}{*}{$-N$} & & - & 3.50 & $6.89 \mathrm{~b}$ & 8.04 & $6.04 \mathrm{~b}$ & 7.07 \\
\hline & SEM & - & 0.09 & 0.56 & 0.19 & 0.24 & 0.29 \\
\hline & Significance & - & $\left({ }^{\star}\right)$ & * & ns & $\star \star \star$ & ns \\
\hline
\end{tabular}

\section{$\operatorname{Spp} \times \mathbf{N}$}

\begin{tabular}{|c|c|c|c|c|c|c|c|}
\hline $\mathrm{BR}+\mathrm{N}$ & & - & $3.39 \mathrm{~cd}$ & 11.0 & 8.03 & 8.42 & 7.71 \\
\hline BR-N & & 2.74 & $2.74 \mathrm{e}$ & 7.22 & 8.28 & 5.69 & 7.28 \\
\hline $\mathrm{CF}+\mathrm{N}$ & & - & $5.92 \mathrm{a}$ & 12.7 & 7.92 & 10.0 & 8.63 \\
\hline CF-N & & 2.48 & $4.01 \mathrm{~b}$ & 7.50 & 8.66 & 5.94 & 8.25 \\
\hline $\mathrm{RG}+\mathrm{N}$ & & - & $3.69 \mathrm{bc}$ & 10.5 & 7.32 & 9.75 & 8.45 \\
\hline RG-N & & 2.41 & 3.91 bc & 7.49 & 8.15 & 5.86 & 6.32 \\
\hline $\mathrm{TF}+\mathrm{N}$ & & - & $3.00 \mathrm{de}$ & 8.80 & 6.28 & 9.19 & 6.07 \\
\hline \multirow[t]{3}{*}{ TF-N } & & 2.04 & $3.35 \mathrm{~cd}$ & 5.36 & 7.07 & 6.67 & 6.43 \\
\hline & SEM & - & 0.19 & 0.88 & 0.44 & 0.59 & 0.68 \\
\hline & Significance & - & $\star \star * *$ & ns & ns & ns & ns \\
\hline
\end{tabular}

${ }^{1} \mathrm{~ns}=$ non-significant, ${ }^{*}=\mathrm{P}<0.05,{ }^{* *}=0.01$ and ${ }^{* * *}=\mathrm{P}<0.01$. Means followed by the same letter are similar at the $\mathrm{P}<0.05$ level.

${ }^{2} \mathrm{~N}$ fertiliser was not applied in 2014/15; Values have been rounded to two significant figures for presentation. SEM is the standard error of the mean. 


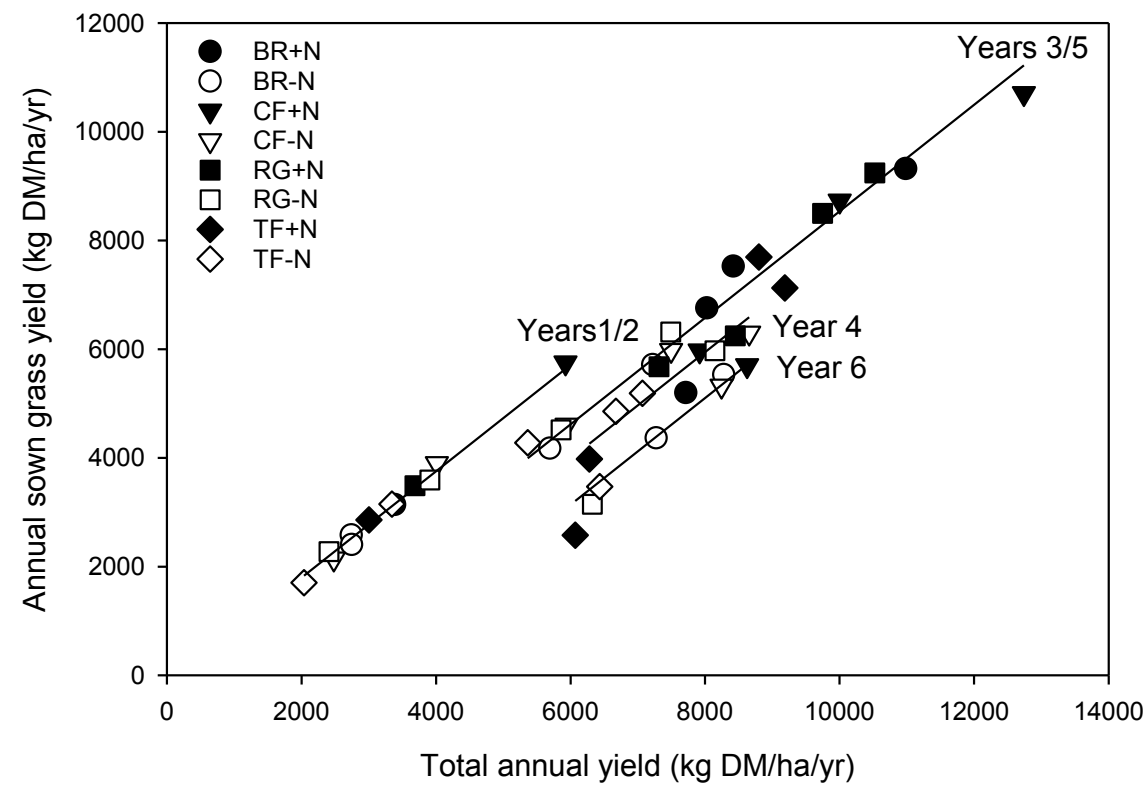

Figure 3 Regression between the annual sown grass yield ( $\mathrm{kg} \mathrm{DM} / \mathrm{ha} / \mathrm{yr}$ ) and total annual yield (kg DM/ha/yr) of four grass monocultures fertilised with $(+\mathrm{N})$ or without $(-\mathrm{N})$ nitrogen in Years 1-6 at Ashley Dene, Canterbury, New Zealand. Grouped parallel line regressions $\left(R^{2}=0.98\right)$ are fitted to groups including Years 1/2: $y=-166( \pm 148)+0.98( \pm 0.03)$ $x$, Years 3/ 5: $y=-1288( \pm 294)+0.98( \pm 0.03) x$, Year 4: $y=-1910( \pm 288)+0.98( \pm 0.03) x$ and Year 6: $y=-2763( \pm 278)+$ $0.98( \pm 0.03) x$. Regression parameters are reported with their respective standard errors $( \pm S E)$.

showed $+\mathrm{N}$ pastures grew $55 \%$ more $(\mathrm{P} \leq 0.01) \mathrm{DM}$ annually than the $-\mathrm{N}$ pastures $(6.04 \pm 0.24 \mathrm{t} \mathrm{DM} / \mathrm{ha})$. In the final year $(2019 / 20)$ a trend $(\mathrm{P} \leq 0.10)$ showed the $7.97 \pm 0.47 \mathrm{t} \mathrm{DM} / \mathrm{ha} / \mathrm{yr}$ produced by $\mathrm{CF}$ and $\mathrm{BR}$ pastures was $29 \%$ more than the $6.25 \mathrm{t} \mathrm{DM} /$ ha produced by the TF pastures. The $7.39 \mathrm{t} \mathrm{DM} /$ ha produced by the $\mathrm{RG}$ pastures was not different to the other treatments.

\section{Relationship between the sown grass component and total annual DM yield}

An all-subsets regression showed a significant effect of growth season on the relationship between annual sown grass yield and total annual DM yield which increased the $\mathrm{R}^{2}$ from 0.86 to 0.98 (Figure 3). Parallel lines were fitted to the four different groups: Years 1 and 2, Years 3 and 5, Year 4 and Year 6. The common slope was $0.98 \pm 0.03$ but intercepts differed among the four groups. The intercept enables the amount of unsown species to be quantified which ranged from $166 \mathrm{~kg} \mathrm{DM} /$ ha in Year 1 to $2763 \mathrm{~kg} \mathrm{DM} / \mathrm{ha}$ in Year 6. The decline $(\mathrm{P}<0.05)$ in contribution of the sown component over time is highlighted in Figure 4, which shows the response to $\mathrm{N}$ in Years 2 and 5 and the decline in the TF component in Year 6.

Metabolisable energy (ME) of the sown grass component in Years 5 and 6

Nutritive analysis of the sown grass component occurred at nine of the 11 grazing periods in the final 2 years of the experiment. Repeated measures analysis showed ME for the six vegetative regrowth cycles was affected by a Spp $\times \mathrm{N}$ interaction. Perennial ryegrass had the highest $(\mathrm{P} \leq 0.05) \mathrm{ME}(11.9 \pm 0.06 \mathrm{MJ} / \mathrm{kg} \mathrm{DM})$

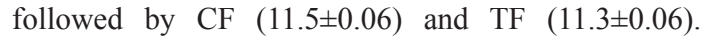
The interaction was primarily caused by different $\mathrm{ME}$ for the BR+N (11.2) and BR-N (10.9) pastures. Additionally, a TimexSpp interaction $(\mathrm{P} \leq 0.05)$ showed $\mathrm{ME}$ ranged from 10.6 MJ/kg DM (BR in May 2020) to $12.4 \pm 0.12 \mathrm{MJ} / \mathrm{kg}$ DM for RG in late winter/early spring (Figure 5).

When sown grasses were reproductive (Nov-Jan) ME decreased linearly as the proportion of total DM yield contributed by reproductive structures increased. The relationship accounted for $70 \%$ of the observed variation (Figure 6).

\section{Weed yield}

Weed yield was low $(0.24 \pm 0.05 \mathrm{t} \mathrm{DM} / \mathrm{ha})$ and did not differ among treatments in the establishment year (2014/15). However, there was a high degree of variability $(\mathrm{CV}=62 \%)$ and a trend $(\mathrm{P} \leq 0.10)$ indicated weeds contributed $4.0 \pm 2.9 \%$ to total annual yield in the faster establishing RG pastures compared with $16 \pm 2.9 \%$ in the slower establishing CF and TF pastures (Figure 7). These were predominantly summer annuals such as fathen. However, they were absent in 2015/16 


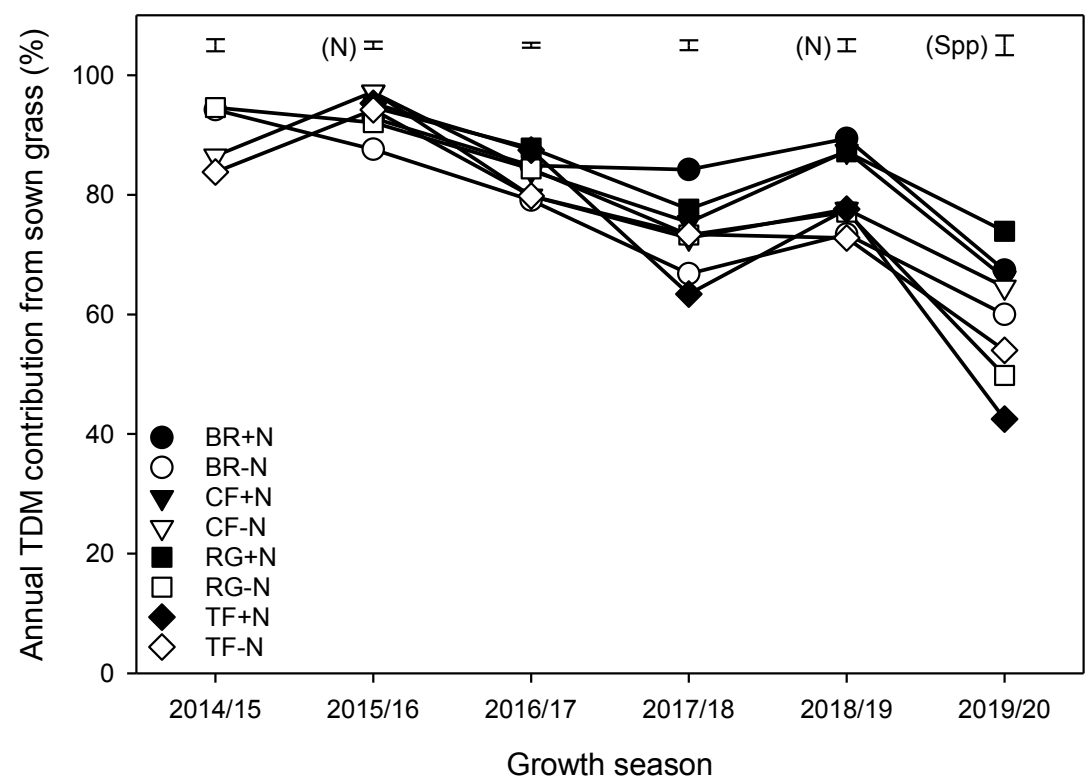

Figure 4 Annual contribution (\%) of the sown grass component to total annual DM yield (TDM) of brome (BR), cocksfoot (CF), perennial ryegrass $(R G)$ and tall fescue $(T F)$ pastures fertilised with $(+N)$ or without $(-N)$ nitrogen at Ashley Dene, Canterbury, New Zealand. Error bars are the SEM for the treatment effects of $N(N)$ in Years 2 and 5 and species (Spp) in Year 6. Pooled SEM is shown in 2014/15, 2016/17 and 2017/18 (Years 1, 3 and 4) where no treatment effects were observed.

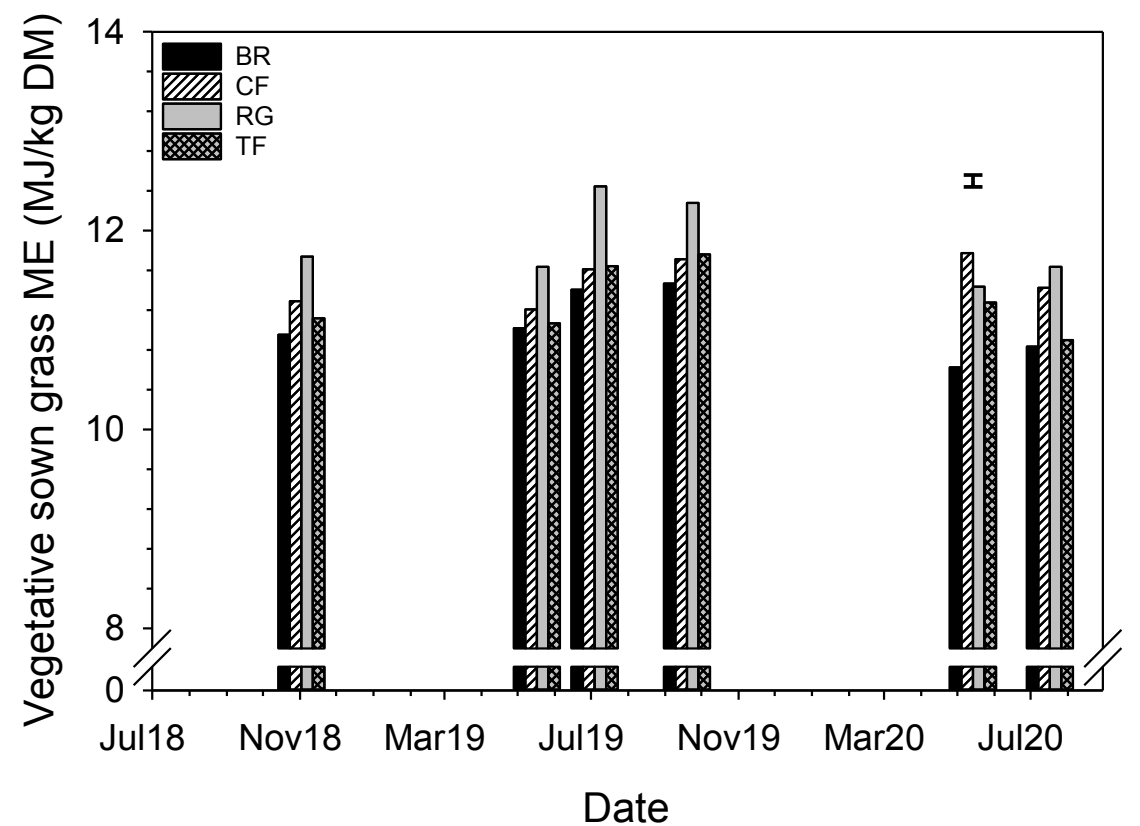

Figure 5 Metabolisable energy (MJ ME/kg DM) of brome (BR), cocksfoot (CF) perennial ryegrass (RG) and tall fescue (TF) at six times when vegetative in Years 5 and 6 . Error bar is the SEM for the Time ${ }^{\times}$Spp interaction.

with no weeds detected. In 2016/17, weed yield was low $(0.11 \pm 0.02 \mathrm{tDM} / \mathrm{ha} / \mathrm{yr})$ at $1.3 \pm 0.3 \%$ of total annual yield and not different amongst treatments.

The contribution from weeds increased substantially in $2017 / 18$ in all pastures $(1.43 \pm 0.14 \mathrm{t} \mathrm{DM} / \mathrm{ha})$. There was a trend $(\mathrm{P} \leq 0.10)$ of more weeds in the total annual yield of TF $(24 \%)$ than in BR or RG $(15 \pm 2.2 \%)$ pastures. In 2018/19 weed species produced $0.74 \pm 0.09$ $\mathrm{t} \mathrm{DM} /$ ha regardless of treatment. However, the annual contribution from $\mathrm{N}$-fertilised pastures was $7.2 \pm 1.2 \%$ 


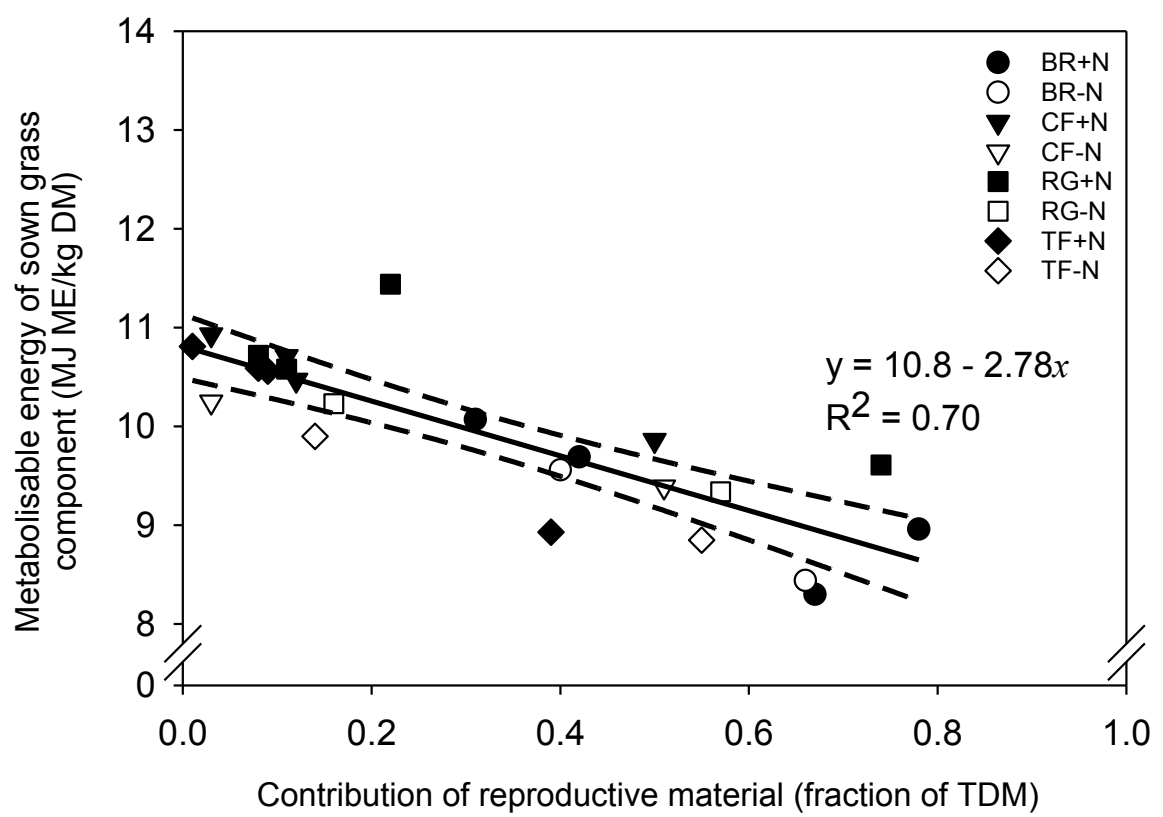

Figure 6 Metabolisable energy of the sown grass against the proportion of total DM (TDM) yield contributed by reproductive material (stems and seedheads) for three harvests taken in November-January in Years 5 and 6 at Ashley Dene, Canterbury, New Zealand. Dashed line is the $95 \%$ confidence interval for the linear regression.

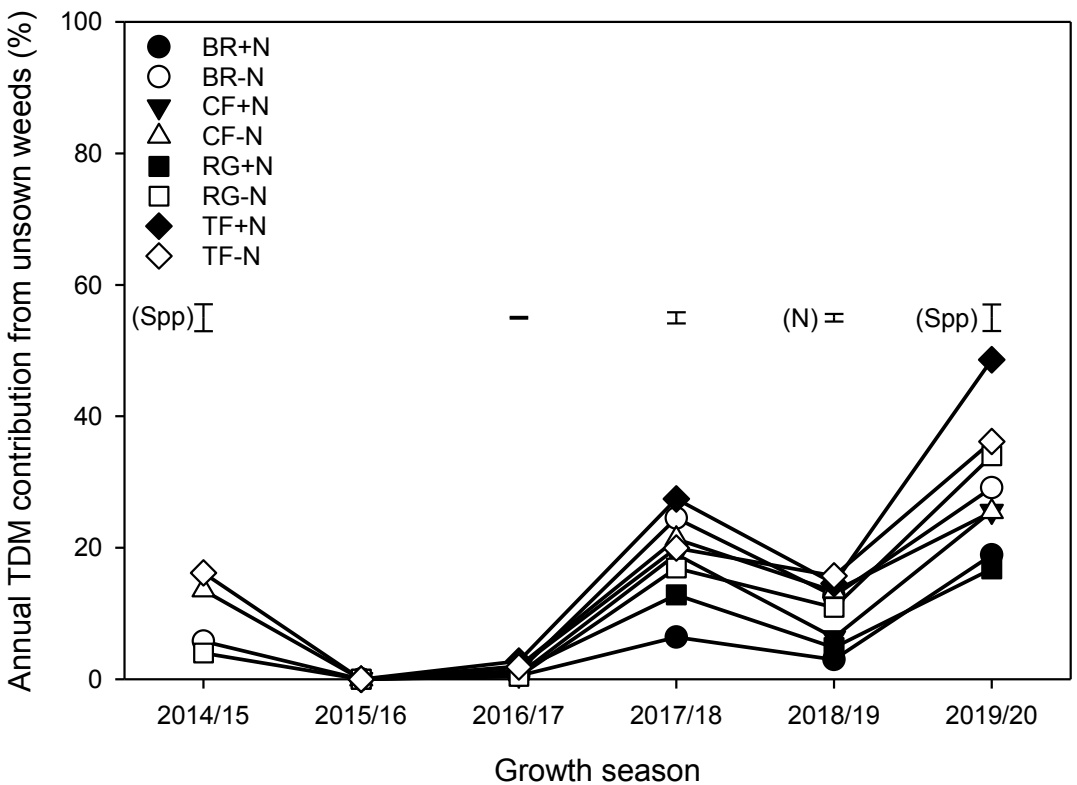

Figure 7 Annual contribution (\%) of unsown weed species to total annual DM yield (TDM) of brome (BR), cocksfoot (CF), perennial ryegrass $(R G)$ and tall fescue $(T F)$ pastures fertilised with $(+N)$ or without $(-N)$ nitrogen at Ashley Dene, Canterbury, New Zealand. Error bars are the SEM for the treatment effects of $\mathrm{N}(\mathrm{N})$ in Years 4 and species (Spp) in Years 2 and 6. Pooled SEM is shown in 2016/17 and 2017/18 (Years 3 and 4) where no treatment effects were observed.

or half $(\mathrm{P} \leq 0.05)$ that of the non-fertilized $(-\mathrm{N} ; 13 \pm 1.2 \%)$ pastures. In the final year $(2019 / 20$; Year 6) weeds yielded $2.10 \pm 0.18 \mathrm{t} \mathrm{DM} / \mathrm{ha}$. This represented $25 \pm 4.0$ (BR, $C F$ and $R G)$ to $(P \leq 0.05) 42 \%$ (TF) of total annual $\mathrm{DM}$ production. The major weed in $\mathrm{CF}, \mathrm{RG}$ and $\mathrm{TF}$ pastures by the end of the experiment was BR, which had established from seed from the BR pastures.

\section{Dead material}

Dead material was minimal in the establishment year 


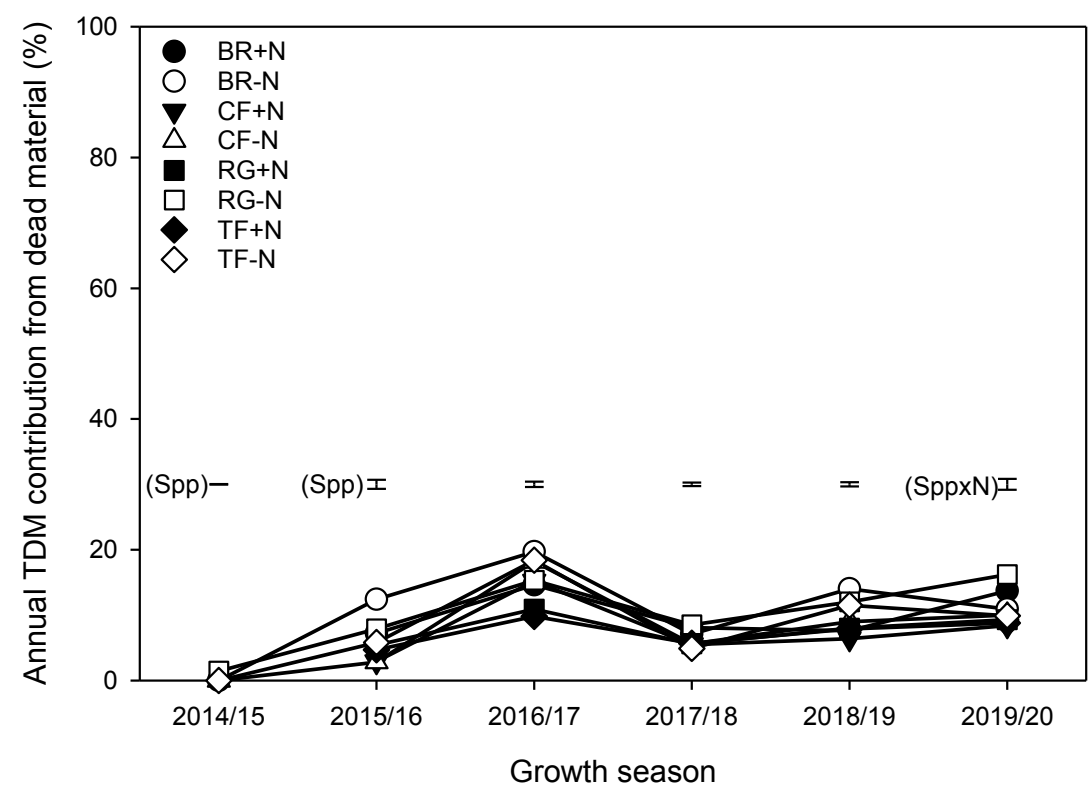

Figure 8 Annual contribution (\%) of dead material to total annual DM yield (TDM) of brome (BR), cocksfoot (CF), perennial ryegrass $(R G)$ and tall fescue $(T F)$ pastures fertilised with $(+N)$ or without $(-N)$ nitrogen at Ashley Dene, Canterbury, New Zealand. Error bars are the SEM for the treatment effects of species (Spp) in Years 1 and 2 and Spp $\times$ N interaction in Year 6. Pooled SEM is shown in 2016/17, 2017/18 and 2018/19 (Years 3, 4 and 5) where no treatment effects were observed.

(2014/15) and accounted for $<1.5 \%$ (Figure 8). In $2015 / 16$ dead material represented $9.8 \%$ of total annual DM yield in the BR pastures compared $(\mathrm{P} \leq 0.05)$ with $4.1 \pm 1.4 \%$ in the $\mathrm{CF}$ and TF pastures. There was no difference in the annual percentage contribution of dead material to total DM yield in $2016 / 17(15 \pm 0.8 \%)$, $2017 / 18(6.4 \pm 0.5 \%)$ or $2018 / 19(9.5 \pm 0.6 \%)$. However, in Year $6(2019 / 20)$ the amount of dead material represented $8.6 \pm 1.7(\mathrm{TF}+\mathrm{N}$ and $\mathrm{CF}+\mathrm{N})$ to $15.0 \pm 1.7 \%$ $(\mathrm{RG}-\mathrm{N}$ and $\mathrm{BR}+\mathrm{N})$ of the total annual yield.

\section{Discussion}

The aim of this study was to compare the production, persistence and quality of four perennial grasses grown over 6 years in a dryland environment. The results showed that in most cases the main effects of species or $\mathrm{N}$ were significant except for the interaction caused by a greater response to $\mathrm{N}$ for $\mathrm{CF}$ and $\mathrm{BR}$ in Year 2 (Table 3).

\section{Species effects}

Across 6 years total annual yield (Table 3) ranged from 2.04 (RG-N; Year 1) to $12.7 \mathrm{t} \mathrm{DM} / \mathrm{ha} / \mathrm{yr}(\mathrm{CF}+\mathrm{N}$; Year 3). In 4 of the 6 years a species effect dominated which showed lower total annual yield from the TF pastures compared with the other species. Poor TF persistence in dryland environments has been reported previously (Smith et al. 1998) and success with this species is dependent on successful initial establishment.
Failures with TF at a range of dryland sites reflect a small optimum window for combined temperature and moisture (hydrothermal time) requirements (Sharifiamina et al. 2016), low seedling vigour and initial poor field establishment (Brock et al. 1982). Poor $\mathrm{N}$ nutrition can reduce stress tolerance (Easton et al. 1994) and overgrazing can reduce root biomass (Gibson 2001). Additionally, TF operates as a 'water spender', whereby osmotic adjustment results in more water loss and less stomatal control as stress develops than a 'water saver' such as RG (Butler 2008). The cultivar of TF used is promoted as an "Oceanic" type. It remains to be seen whether a more summer-dormant type would have greater persistence in this extremely dry environment.

As expected, TF and $\mathrm{CF}$, with their higher thermal time requirements for germination and establishment (Moot et al. 2000), had a higher weed content than the faster establishing RG and BR in the establishment year (Figure 7). Weeds were subsequently supressed through direct competition and a broadleaf herbicide application in May 2015. Weed load remained relatively low in all pastures throughout the next two growth seasons, before increasing from Year 4 as sown grass contributions started to decline (Figure 4). Previous work has shown $\mathrm{RG}$ fails to persist in warm and dry environments (MacFarlane 1990; Fraser 1994; Easton et al. 2011) and is best suited to mild temperate environments with low pest pressure and limited exposure to water 
deficits (Milne 2011). The general lack of difference in sown grass yield among BR, CF and RG pastures reported here (Table 3 ) may reflect the optimum dryland grazing management employed. An AR1-infected RG cultivar was sown, there was negligible pest pressure and plots were periodically grazed for 1 or 2 days when there was adequate feed for livestock in the first 4 years. Thus, under these dryland conditions the RG was periodically exposed to a single stress factor (lack of water) rather than multiple stresses (water/pests/N/ grazing pressure) interacting together which can cause faster rates of pasture deterioration (Daly et al. 1999; Moot et al. 2021). For BR, there is also potential for annual weed BR species to have been included in the composition component that could have distorted the result. Regardless, there did appear to be evidence of an emerging interaction in the final year where $\mathrm{RG}+\mathrm{N}$ pastures contained more RG than the RG-N pastures (Figure 4). Previous work showed, over 9 years, the contribution from originally sown species declined at $\sim 3 \% / y r$ for CF-based pastures compared with $10 \% / y r$ for the RG-based pasture over a 10-year period (Mills et al. 2014). This would suggest $C F$ would remain dominant in the monocultures beyond Year 6 while TF and RG-N pastures may continue to deteriorate. Total annual DM production of these grass-based pastures sown with companion legumes, on a deeper soil, ranged from 5.2 to $12.9 \mathrm{t} \mathrm{DM} / \mathrm{ha} / \mathrm{yr}$, which is comparable to the range reported in Years 3-6 (Table 3). Chapman et al. (2021) reported annual yields of dryland RG dairy pastures in Waikato were 6.1 to $19.1 \mathrm{t} \mathrm{DM} / \mathrm{ha} / \mathrm{yr}$ with the contribution of RG declining from $71 \%$ in Year 1, which had the highest annual production, to $39 \%$ in Year 8 .

The regression between ME of the sown grass component and the proportion of reproductive material present in the sward (Figure 5) explained $70 \%$ of the observed variation, which was not different among treatments. As expected, the ME declined as the quantity of lower quality structural material increased due to a higher proportion of reproductive material. The consistency of the result suggests a single relationship could be used to estimate total pasture quality with different levels of reproductive material. Of note, the ME value only declined to $8.0 \mathrm{MJ} \mathrm{ME} /$ $\mathrm{kg}$ DM, which is similar to hay (de Ruiter et al. 2007), when the proportion of reproductive material was $\sim 80 \%$. This suggests that in dryland environments this standing stem would be adequate maintenance feed for dry ewes.

\section{Nitrogen effect}

Nitrogen effects occurred in Years 3 and 5 showing all species responded similarly to applied N. However, the $\mathrm{Spp} \times \mathrm{N}$ interaction in Year 2 occurred because neither $\mathrm{RG}$ or TF responded to $\mathrm{N}$ (Table 3). The plateau in DM accumulation in Year 4 (2017/18) was caused by lack of water with only $2 \mathrm{~mm}$ of rain falling in November and $29 \mathrm{~mm}$ in December (Figure 1a). January rainfall (106 $\mathrm{mm}$ ) was more than double the long-term mean and was sufficient to allow pasture growth to resume but resulted in lower than expected total annual production (Table 3) given the $495 \mathrm{~kg} \mathrm{~N} / \mathrm{ha}$ applied to promote growth. The observed species effect thus indicates a critical limiting factor response where water deficiency dominated and restricted the ability of the pastures to access applied $\mathrm{N}$ during the peak production period. In contrast, Year $3(2016 / 17)$ had adequate rainfall to maintain growth over the summer period, which resulted in the highest annual production with $+\mathrm{N}$ pastures producing $56 \%$ more DM than $-\mathrm{N}$ pastures (Table 3). It should also be noted that results in the first 4 years are likely to reflect some $\mathrm{N}$ transfer from $+\mathrm{N}$ pastures to $-\mathrm{N}$ pastures by grazing livestock. With the advent of cut and carry management in late spring of Year 5 the expected yield response to $\mathrm{N}$ was observed but was not maintained in Year 6.

For grasses, $\mathrm{N}$ fertiliser can enhance $\mathrm{DM}$ production and maximize water use efficiency (Mills et al. 2006). However, no response to applied $\mathrm{N}$ would be expected when the soil dries and nutrient uptake is compromised (Mills et al. 2009) which explains the lack of CF N response in Year 6 when rainfall was about half the long-term mean from December to May (Figure 1). No $\mathrm{N}$ response occurred in any of the four regrowth cycles, and no $\mathrm{N}$ was applied in the first regrowth cycle. Brome pastures produced about half the yield of the RG pastures at the September harvest. The second regrowth cycle accounted for most of the annual yield as pastures were allowed to go reproductive during a 2-month regrowth cycle where $\mathrm{CF}$ and BR out-yielded TF pastures mainly due to reproductive seedheads (data not shown). No treatment effects occurred in the May or July rotations when water deficits and low temperature limited growth and $\mathrm{N}$ responses. For 'Grasslands Wana' $\mathrm{CF}$ managed under dryland cut and carry conditions, non-limiting $\mathrm{N}$ increased annual yield from $\sim 6.3$ to 15.7 t DM/ha (Mills et al. 2006) and similarly showed no difference in yield when water constrained growth in summer months. These pastures had more ability to respond to applied $\mathrm{N}$ due to a greater plant available water holding capacity in the root zone compared with the shallow stony Lowcliffe soils used in the current experiment. Ideally, $\mathrm{N}$ would be supplied to the grass by including a suitable companion legume, such as subterranean clover (Trifolium subterraneum) in a mixed species pasture. This would be recommended to reduce the reliance on inorganic $\mathrm{N}$ fertiliser and provide high quality vegetative feed (Figure 5) to grazing livestock. Nitrogen has been reported to increase CF dominance in a sward (Smith et al. 1998) and increased interspecific competition is beneficial in preventing 
weed ingress over time but can be detrimental to maintaining companion clover content (Lee \& Cho 1985), particularly when the mix contains species where the peak resource demand period is not seasonally offset (Mills et al. 2014). Cocksfoot is recognised for its persistence in low fertility environments and responds to increases in fertility (Smith et al. 1998).

\section{Conclusions/Practical implications/Relevance}

- Tall fescue persistence was reduced in this summerdry, water-deficient environment on a shallow and stony soil.

- In contrast, the water deficits alone resulted in no differences in brome, cocksfoot and AR1 perennial ryegrass yields in 5 out of 6 years.

- Nitrogen application on soils of low water holding capacity, analogous to sunny faces on hill country, only showed a response to $\mathrm{N}$ in spring when soil water was available. The use of an annual legume such as subterranean clover may be more appropriate to provide $\mathrm{N}$ in such an unreliable environment.

- $70 \%$ of the observed variation in ME of the sown grass was accounted for by the increase in the proportion of reproductive seed heads present across species.

\section{ACKNOWLEDGEMENTS}

Funding for this project was provided by Beef + Lamb New Zealand, the Ministry of Business, Innovation and Employment, Seed Force New Zealand and PGG Wrightson Seeds under the "Hill Country Futures" research programme (BLNZT1701). The authors thank Dr K.M. Pollock for data collection in Years 3 and 4.

\section{REFERENCES}

Barenbrug New Zealand. 2021. Pasture and forage manual. $256 \mathrm{p}$.

Brock JL, Anderson LB, Lancashire JA. 1982. Grasslands Roa tall fescue - seedling growth and establishment. New Zealand Journal of Experimental Agriculture 10: 285-289. https://doi.org/10.1080/030 15521.1982.10427884

Brown RW. 1995. Water relations of range plants. In: Bedunah DJ \& Sosebee RE. Eds. Wildland plants; Physiological, ecological and developmental morphology. Denver, United States of America: Society for Range Management, pp. 291-413.

Butler TR. 2008. Physiological effects of drought on perennial ryegrass (Lolium perenne L.) and tall fescue (Festuca arundinacea Schreb.). M.Ag. Sci. thesis, Lincoln Unversity, Christchurch, New Zealand. 149 p. https://hdl.handle.net/10182/1098

Cayley JWD, Bird PR. 1996. Techniques for Measuring Pastures. 2nd edition. Pastoral and Veterinary Institute, Hamilton, Victoria, Australia. 51 p.
Chapman DF, Ludemann CI, Griffiths WM, Rossi L, Waugh D, Kuhn-Sherlock B. 2021. Persistence of the yield advantage of perennial ryegrass cultivars: concept, evidence and implications. In: Douglas GB. Ed. Resilient Pastures Symposium. Grassland Research and Practice Series 17. Dunedin, New Zealand: New Zealand Grassland Association, pp. 411-420. https://doi.org/10.33584/rps.17.2021.3452

Daly MJ, Fraser T, Perkins A, Moffat CM. 1999. Farmer perceptions of reasons for perennial pasture persistence and relationship of these with management practice, species composition, and soil fertility. Proceedings of the New Zealand Grassland Association 61: 9-15. https://doi.org/10.33584/ jnzg.1999.61.2348

de Ruiter JM, Dalley DE, Hughes TP, Fraser TJ, Dewhurst RJ. 2007. Types of supplements: Their nutritive value and use. In: Rattray PV, Brookes IM \& Nichol AM. Eds. Pasture and Supplements for Grazing Animals. Occasional Publication 14. Christchurch, New Zealand: New Zealand Society of Animal Production (Inc.), pp. 97-115.

Easton HS, Lee CK, Fitzgerald RD. 1994. Tall fescue in Australia and New Zealand. New Zealand Journal of Agricultural Research 37: 405-417. https://doi.org/1 0.1080/00288233.1994.9513078

Easton HS, Stewart AV, Kerr GA. 2011. Ryegrass in pastures - breeding for resilience. In: Mercer CF. Ed. Pasture Persistence Symposium. Grassland Research and Practice Series 15. Dunedin, New Zealand: New Zealand Grassland Association, pp. 139-148. https:// doi.org/10.33584/rps.15.2011.3208

Fraser TJ. 1994. Persistence of dryland pasture species in mixed swards in Canterbury. Proceedings of the New Zealand Grassland Association 56: 77-79. https://doi.org/10.33584/jnzg.1994.56.2136

Gibson DJ. 2001. Festuca arundinacea Schreber (F. elatior L. ssp. arundinacea (Schreber) Hackel). Journal of Ecology 89: 304-324. https://doi. org/10.1046/j.1365-2745.2001.00561.x

IPCC. 2021. Summary for policymakers. In: MassonDelmotte V, Zhai P, Pirani A, Connors SL, Péan C, Berger S, Caud N, Chen Y, Goldfarb L, Gomis MI, Huang M, Leitzell K, Lonnoy E, Matthews JBR, Maycock TK, Waterfield T, Yelekçi O, Yu R \& Zhou B. Eds. Climate Change 2021: The Physical Science Basis. Contribution of Working Group I to the Sixth Assessment Report of the Intergovernmental Panel on Climate Change. Cambridge University Press (In press). https:// www.ipcc.ch/report/ar6/wg1/\#SPM

Jamieson PD, Brooking IR, Porter JR, Wilson DR. 1995. Prediction of leaf appearance in wheat: a question of temperature. Field Crops Research 41: 35-44. https:// doi.org/10.1016/0378-4290(94)00102-I 
Kerr GA, Brown J, Kilday T, Stevens DR. 2015. A more quantitative approach to pasture renewal. Journal of New Zealand Grasslands 77: 251-258. https://doi. org/10.33584/jnzg.2015.77.460

Knowles IM, Fraser TJ, Daly MJ. 2003. White clover: loss in drought and subsequent recovery. In: Moot DJ. Ed. Legumes for Dryland Pastures. Grassland Research and Practice Series 11. Dunedin, New Zealand: New Zealand Grassland Associaion, pp. 3741. https://doi.org/10.33584/rps.11.2003.2997

Lee HJ, Cho MJ. 1985. Root competition and productivity in mono- and binary association of four forage species. Proceedings of the XV International Grassland Congress, Kyoto, Japan, 24-31 August, pp. 663-665.

MacFarlane AW. 1990. Field experience with new pasture cultivars in Canterbury. Proceedings of the New Zealand Grassland Association 52: 139-143. https://doi.org/10.33584/jnzg.1990.52.1977

Manaaki Whenua - Landcare Research. 2019. S-map New Zealand's national digital soil map. https://doi. org/10.7931/L1WC7

McLenaghen R, Webb TH. 2012. Soil properties and fertility of Ashley Dene: the challenge. In: Lucas RJ, Gow N \& Nichol A. Eds. Ashley Dene Lincoln University Farm: the first 100 years. Christchurch, New Zealand: Lincoln University, pp. 17-22. https:// livingheritage.lincoln.ac.nz/nodes/view/33142

Mills A, Moot DJ, McKenzie BA. 2006. Cocksfoot pasture production in relation to environmental variables. Proceedings of the New Zealand Grassland Association 68: 89-94. https://doi.org/10.33584/ jnzg.2006.68.2636

Mills A, Moot DJ, Jamieson PD. 2009. Quantifying the effect of nitrogen on productivity of cocksfoot (Dactylis glomerata L.) pastures. European Journal of Agronomy 30: 63-69. https://doi.org/10.1016/j. eja.2008.07.008

Mills A, Lucas RJ, Moot DJ. 2014. 'MaxClover' Grazing Experiment: I. Annual yields, botanical composition and growth rates of six dryland pastures over nine years. Grass and Forage Science 70: 557570. https://doi.org/10.1111/gfs.12132

Mills A, Thomson BC, Muir PD, Smith NB, Moot DJ. 2021. Resident hill country pasture production in response to temperature and soil moisture over 20 years in Central Hawke's Bay. In: Douglas GB. Ed. Resilient Pastures Symposium. Grassland Research and Practice Series 17. Dunedin, New Zealand: New Zealand Grassland Association, pp. 253-262. https:// doi.org/10.33584/rps.17.2021.3451

Milne GD. 2011. Can pasture persistence be improved through the use of non-ryegrass species? In: Mercer CF. Pasture Persistence Symposium. Grassland Research and Practice Series 15. Dunedin, New
Zealand: New Zealand Grassland Association, pp. 157-162. https://doi.org/10.33584/rps.15.2011.3197

Ministry for the Environment. 2018. Climate Change Projections for New Zealand: Atmosphere Projections Based on Simulations from the IPCC Fifth Assessment. 2nd edition. Ministry for the Environment, Wellington, New Zealand. 131 p. https:/environment.govt.nz/assets/Publications/ Files/Climate-change-projections-2nd-edition-final. pdf

Moot DJ, Scott WR, Roy AM, Nicholls AC. 2000. Base temperature and thermal time requirements for germination and emergence of temperate pasture species. New Zealand Journal of Agricultural Research 43: 15-25. https://doi.org/10.1080/002882 33.2000.9513404

Moot DJ, Anderson PVA, Anderson LJ, Anderson DK. 2019. Animal performance changes over 11 years after implementing a lucerne grazing system on Bog Roy Station. Journal of New Zealand Grasslands 81: 75-80. https://doi.org/10.33584/jnzg.2019.81.390

Moot DJ, Black AD, Lyons EM, Egan LM, Hofmann RW. 2021. Pasture resilience reflects differences in root and shoot responses to defoliation, and water and nitrogen deficits. In: Douglas GB. Ed. Resilient Pastures Symposium. Grassland Research and Practice Series 17. Dunedin, New Zealand: New Zealand Grassland Association, pp. 71-80. https:// doi.org/10.33584/rps.17.2021.3472

NIWA. 2019. Water balance. Retrieved 16 January 2019 from: https://cliflo.niwa.co.nz/pls/niwp/wh.do_ help?id=ls_ra_wb

Power DR, Pollock KM, Lucas RJ, Moot DJ. 2006. Clover species cover on summer dry hill country in Central Otago. Proceedings of the New Zealand Grassland Association 68: 343-347. https://doi. org/10.33584/jnzg.2006.68.2615

Salinger J. 2003. Climate reality - actual and expected. In: Moot DJ. Ed. Legumes for Dryland Pastures. Grassland Research and Practice Series 11. Dunedin, New Zealand: New Zealand Grassland Associaion, pp. 13-18. https://doi.org/10.33584/rps.11.2003.2999 Sharifiamina S, Moot DJ, Bloomberg M. 2016. Calculating "hydrothermal time" to quantify seed germination of tall fescue. Journal of New Zealand Grasslands 78: 163-168. https://doi.org/10.33584/ jnzg.2016.78.499

Sharifiamina S. 2018. Agronomic and physiological performance of four perennial grasses under summer dry conditions in New Zealand, Ph.D thesis, Lincoln University, Christchurch, New Zealand. 196 p. https://hdl.handle.net/10182/10200

Smith DR, Fraser TJ, Moffat CA, Daly MJ. 1998. Effects of soil fertility on the persistence of dryland cocksfoot and tall fescue pastures. Proceedings of the 
New Zealand Grassland Association 60: 265-270. https://doi.org/10.33584/jnzg.1998.60.2288

Stevens DR, Casey MJ, Edwards JP, Maxwell TMR. 2021. A systems approach to understanding the connection between farm systems resilience and pasture resilience. In: Douglas GB. Ed. Resilient Pastures Symposium. Grassland Research and Practice Series 17. Dunedin, New Zealand: New Zealand Grassland Association, pp. 421-432. https:// doi.org/10.33584/rps.17.2021.3467 
